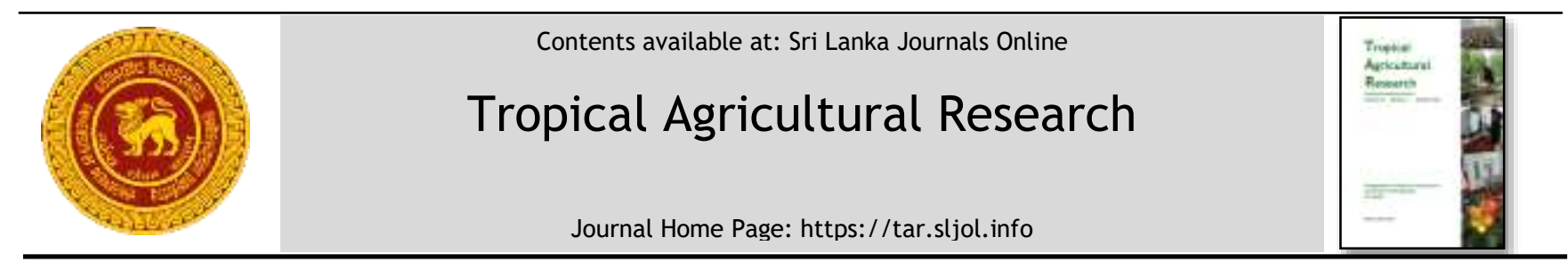

\title{
Characterization of Lactic Acid Bacteria Isolated from Idli Batter and their Susceptibility to Antibiotics
}

\author{
D Bernard ${ }^{1 *}, \mathrm{~N}$ Jeyagowri², T Madhujith ${ }^{3}$ \\ ${ }^{1}$ Postgradaute Institute of Agriculture, University of Peradeniya, Sri Lanka. \\ ${ }^{2}$ Department of Bioscience, Faculty of Applied Science, Vavuniya Campus of the University of Jaffna. Vavuniya, Sri Lanka \\ ${ }^{3}$ Department of Food Science and Technology, Faculty of Agriculture, University of Peradeniya. Peradeniya, 20400, Sri \\ Lanka
}

\section{ARTICLE INFO}

\section{Article history:}

Received: 31 July 2020

Revised version received: 20 October 2021

Accepted: 25 January 2021

Available online: 010ctober 2021

\section{Keywords:}

Biochemical

Chloromphenicol

Erythromycin

Idli batter

Lactic acid bacteria

\section{Citation:}

Bernard, D., Jeyagowri, N. and Madhujith,

T. (2021). Characterization of lctic acid bacteria isolated from Idli batter and their susceptibility to antibiotics. Tropical Agricultural Research, 32(4): 453-461.

DOI: http://doi.org/10.4038/tar.v32i4.8513

Bernard, D.

https://orcid.org/0000-0002-8137-472X

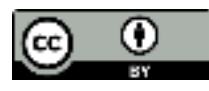

\section{ABSTRACT}

Idli is a common flour based fermented food prepared using lactic acid bacteria which bear probiotic properties, consumed in Sri Lanka and some parts of India. The objective of the present study was to characterize the lactic acid bacteria from idli batter, identify the changes of acidity during fermentation and to determine the antibiotic sensitivity of isolates. Lactic acid bacteria were isolated and characterized up to genus level. Subsequently, antibiotic susceptibility of isolates against four antibiotics was studied. Changes of $\mathrm{pH}$, lactic acid bacterial count and titratable acidity with fermentation were determined. The $\mathrm{pH}$ value dropped steadily from 6.28 to 3.72 while titratable acidity increased from 0.24 to $0.92 \%$ during the fermentation period of 0 to $32 \mathrm{~h}$. With fermentation, the lactic acid bacterial count was increased up to $9.88 \log 10 \mathrm{cfu} / \mathrm{g}$ after 12 hours of fermentation and the count reduced with increasing acidity. A bacterial count of $5.91 \log 10 \mathrm{cfu} / \mathrm{g}$ was recorded at the end of 32 hours of fermentation. Ten lactic acid bacteria isolates were identified from idli batter, of which six isolates were rod shaped and other four were cocci. All isolates were Gram positive, nonmotile, non-spore formers and catalase negative. According to the above tests, it was confirmed up to the genus level that all strains belonged to Lactic acid bacteria. All isolates were susceptible to more than two antibiotics. The diameter of the zone of inhibition ranged from 1-23 mm. The highest zone of inhibition was observed in isolates I- 6 against chloromphenicol (23 $\mathrm{mm})$ while the lowest zone of inhibition was observed in isolates I- 2 against erythromycin $(1 \mathrm{~mm})$. With fermentation the biochemical and sensory qualities of idli batter were changed. Lactic Acid Bacteria isolates showed different sensitivity towards antibiotics tested.

\footnotetext{
*Corresponding author: diluckmini@gmail.com
} 


\section{INTRODUCTION}

Fermentation is considered the oldest food preservation method yet fermented foods are popular even today across the world. In fact, fermented foods are gaining an ever-increasing momentum due to their health benefits. In fermentation, lactic acid bacteria (LAB) play a major role and the optimum amount of acid production varies with the product type.

Isolation and screening of new probiotic strains of LAB from fermented products is important as these micro florae may possess strong probiotic functionalities such as the ability to produce organic acids, exopolysaccharides, proteolytic products and production of antimicrobial activity against many foods borne pathogens (El-Soda et al., 2003; Ayad et al., 2004; Abd El Gawad et al., 2010 and Ayad and Shokery, 2011).

Even though the LAB are widely used and generally recognized as safe (GRAS) for usage and consumption, studies have shown that some of the LAB acquire antibiotic resistance (Clementi and Aquilanti, 2011). Further, the resistance character can be transmitted through the food chain in human and subsequently it may transfer to pathogenic bacteria. Hence, it is important to evaluate the antibiotic resistance of LAB before use them as food or starter cultures (Rodríguez-Alonso et al., 2009).

Most traditional Asian fermented foods are nondairy products prepared using different non-dairy raw materials such as cereals, pulses, fruits, and vegetables, as well as fish and other marine products. LAB initiate relatively rapid growth in various plant materials over a wide range of temperatures and salt concentrations. A vast majority of Sri Lankans and Indians consume fermented traditional products as their breakfast and dinner. Yoghurt rice, "dosa", "idli" and hoppers are some examples of traditional cereal based fermented foods (Wickramanayake, 2002). Idli is a cereal and legume based fermented food, manufactured using LAB. Raw materials used for the preparation of idli batter are rice (Oryza sativa) and dehulled black gram (Phaseolus mungo). Following fermentation, Idli batter is steamed and formed into round shaped, white coloured, soft and porous textured product (Reddy et al., 1982; Shetty et al., 2005). Some of the LAB involved in fermentation may possess probiotic potential. Some studies have shown that Idli batter has LAB with probiotic potential. Those strains are Lactobacillus collinoides (Patel et al., 2012), Lueconostoc mesenteroides, Streptococcus faecalis, Pediococcus cerevisiae (Mukherjee et al., 1965),
Lactobacillus delbrueckii (Soni et al., 1986) and Lactococcus lactis, Lactobacillus plantarum (Iyer et al., 2011). The antibiotic sensitivity of probiotic microorganisms is an important characteristicin determining their suitability for practical applications.

Considering the availability of probiotic potential LAB in Idli batter, their contribution to biochemical changes of Idli batter which improves the sensory quality of end product and therapeutic potential, the present study was conducted to isolate and characterize the novel strains from Idli batter and identify their antibiotic sensitivity.

\section{METHODOLOGY}

Black gram (Phaseolus mungo) and parboiled rice (Oryza sativa) were procured from local market in Vavuniya. All microbiological media and chemicals were obtained from HiMedia, India. The standard antibiotic discs were procured from Oxoid, UK. Idli batter was prepared by the procedure described by Wickramanayake, (2002). The black gram and parboiled rice were soaked in water separately for four to six hours. The seed coat of black gram was removed, mixed in the proportion of 1 to 2 , mashed and left overnight.

\section{Isolation of LAB}

deMan Rogosa and Sharpe (MRS) agar medium was used for isolation of LAB as reported previously by De Man et al. (1960). The pH of the MRS medium was maintained at 6.2. Idli batter (1 g) was suspended in $9 \mathrm{ml}$ of $0.9 \%$ saline water and subjected to serial dilutions. Diluted mixture $[0.1$ $\mathrm{ml}$ ) was pipetted out and spread on the surface of an MRS medium agar plate. The plates were incubated in the inverted position for $48 \mathrm{~h}$ at $37^{\circ} \mathrm{C}$ under anaerobic conditions using candle jar technique.

Ten well developed characteristic colonies growing on the MRS medium were picked up carefully and purified by streaking on MRS agar medium plates following four-way streaking technique and subsequently purified for 4 to 5 times to get pure cultures. The discrete single purified colonies were picked up and transferred into MRS broth in culture vials and the grown-out cultures were maintained at $4^{\circ} \mathrm{C}$ in a refrigerator for further analysis (Pal et al., 2005). To prepare fresh pure cultures for further analysis the preserved pure cultures were activated in MRS agar by streaking and incubated at $37^{\circ} \mathrm{C}$ under 
anaerobic condition for $48 \mathrm{~h}$ before experimental use.

\section{Identification and biochemical characterization}

For pure cultures, Gram staining as described by Rangaswamy and Bagyaraj (1993) was carried out for morphological examination. Catalase activity (Gerhardt et al., 1981), motility test (Barrow and Felthman, 1993) and spore forming ability (Barrow and Felthman, 1993) were used for biochemical identification of LAB from Idli batter.

In brief, the Gram characteristics of the isolates were determined for the LAB isolates grown $48 \mathrm{~h}$ using light microscope following staining. The Gram stained slides were observed under oil immersion $(10 \times 100)$ of light microscope and the cell morphology of LAB was observed as described by Becking (1974). Catalase test was done by transferring a loopful of LAB culture grown over 48 $\mathrm{h}$ into a glass test tube containing $0.5 \mathrm{ml}$ distilled water and mixing thoroughly with $0.5 \mathrm{ml}$ of $3 \%$ hydrogen peroxide solution. Subsequently, the effervescence was observed.

"Hanging drop method" was used to examine the motility of strains. At the centre of a coverslip the bacterial culture was dropped and each corner of the coverslip a drop of paraffin wax was placed. Over the coverslip a cavity slide was inverted to suspend the bacterial culture in the cavity slide's central depression. Finally, the motility was observed under high-power dry objective (x40) with reduced illumination.

For endospore staining a thin smear of bacterial smear was prepared under aseptic conditions was formed on a microscopic slide, and heat fixed. Then the slide was placed over a steaming water bath and malachite green (primary stain) was applied for $5 \mathrm{~min}$ on the slide while covering the slide with blotting paper. Then the slide was removed from the water bath, the blotting paper was removed and the slide was rinsed with water until water turned clear. Then the slide was flooded with the counter stain safranin for $20 \mathrm{~s}$ and rinsed with water. Subsequently the slide was blotted-dried and observed using oil immersion lens.

\section{Measurements during fermentation}

The freshly prepared idli batter was allowed to ferment and during fermentation, samples of nearly $25 \mathrm{~g}$ were obtained from idli batter every 4 $\mathrm{h}$ interval up to $32 \mathrm{~h}$ and LAB counts were determined. The $\mathrm{pH}$ (Sension+ $\mathrm{PH}$ 31-Spain) and titratable acidity was determined every $4 \mathrm{~h}$ time interval up to $32 \mathrm{~h}$ of fermentation. After 4, 8, 12 and $16 \mathrm{~h}$ of fermentation, sensory attributes were determined based on a 5-point hedonic scale using a panel of 30 untrained panellists, who are familiar with Idli since childhood.

\section{Evaluation of antibiotic susceptibility}

The antibiotic activity of isolates was determined by Kirby Baeur disk diffusion method. All isolates were screened for their susceptibility to Amoxicillin (20 $\mu \mathrm{g} /$ disc), Erythromycine (15 $\mu \mathrm{g} /$ disc $)$, Chloromphenicol (30 $\mu \mathrm{g} /$ disc $)$ and Ciprofloaxacin (5 $\mu \mathrm{g} /$ disc). MRS agar was used as a basal medium for bacterial growth. Cell number of LAB isolates were adjusted by changing the absorbance $\left(A_{600 \mathrm{~nm}}\right)$ to 1 by using Phosphate Buffer Saline, pH 7.1 (10 mM Na $2 \mathrm{HPO}_{4}, 1 \mathrm{mM} \mathrm{KH}_{2} \mathrm{PO}_{4}, 140$ $\mathrm{mMNaCl}, 3 \mathrm{mMKCl}$ ) in order to standardize the number of bacteria $\left(10^{7}-10^{8} \mathrm{CFU} / \mathrm{mL}\right)$ and the cultures were spread on the surface of MRS agar using sterile cotton swabs. Above mentioned four standard antibiotic discs (Oxoid, UK) were placed on the inoculated plates with sterile conditions and incubated anaerobically at $37^{\circ} \mathrm{C}$ for $24 \mathrm{~h}$. The diameter of the inhibition zone was measured following incubation. Breakpoints for the interpretation of inhibition zone was defined by expressed in terms of resistance (R), Intermediate (I) and susceptibility (S) according to the National Committee for Clinical Laboratory Standards, NCCLS (NCCLS, 1997).

\section{RESULTS AND DISCUSSION}

Well-developed characteristic presumptive LABs were isolated from idli batter. The characteristic colonies were identified on the surface of MRS agar Petri plate. Different type of colonies: Punctiform, small, moderate and large size colonies were observed on the surface. All colonies were nonpigmented in other words, creamy to white (Table 1).

The isolates were characterized further on the basis of their morphology, culture and biochemical characteristics named as phonotypical characteristics. Based on Gram staining, all isolates were Gram positive, 6 isolates were rod shaped while other 4 were cocci shaped. In case of endospore test, the isolates without green stained spores were termed non-spore formers. All cultures showed negative result thus they were identified as non-spore formers. The motility test has proven all isolates were shown non-motile behaviour. Catalase test is used to determine if bacteria possess catalase enzyme which can detoxify $\mathrm{H}_{2} \mathrm{O}_{2}$. The LABs are negative to catalase 
Table 1: Morphological characteristics of LAB isolates from idli batter

\begin{tabular}{cllllllll}
\hline Isolate & Shape & Margin & Eleva. & Size & Texture & Appe. & Pigmen. & $\begin{array}{l}\text { Opt. } \\
\text { densi. }\end{array}$ \\
\hline I-1 & Circular & Entire & Raised & Moderate & Smooth, Moist & Shiny & Non-pig & Opaque \\
I-2 & Circular & Entire & Raised & Large & Smooth, Moist & Shiny & Non-pig & Opaque \\
I-3 & Circular & Entire & Raised & Puncti form & Smooth, Moist & Shiny & Non-pig & Opaque \\
I-4 & Irregular & Entire & Raised & Moderate & Smooth, Moist & Shiny & Non-pig & Opaque \\
I-5 & Circular & Entire & Raised & Small & Smooth, Moist & Shiny & Non-pig & Opaque \\
I-6 & Spindle & Entire & Raised & Large & Smooth, Moist & Shiny & Non-pig & Opaque \\
I-7 & Irregular & Entire & Raised & Small & Smooth, Moist & Shiny & Non-pig & Opaque \\
I-8 & Irregular & Entire & Raised & Large & Smooth, Moist & Shiny & Non-pig & Opaque \\
I-9 & Spindle & Entire & Raised & Moderate & Smooth, Moist & Shiny & Non-pig & Opaque \\
I-10 & Spindle & Entire & Raised & Small & Smooth, Moist & Shiny & Non-pig & Opaque \\
\hline Eleva.- - elevation; Appe. - appearance; Pigmen.- pigmentation; Opt. densi. - optical density & &
\end{tabular}

test as they neither possess peroxidase enzyme nor produce bubbles when mixed with $3 \%$ hydrogen peroxide. Catalase test for all ten isolates was negative. This showed the absence of catalase enzyme and confirms that the isolates belong to LAB. From isolated 10 colonies, 6 isolates were found to be Gram positive, rods, non-motile, nonspore formers and negative to catalase activity, belonging to Lactobacillus spp. Other 4 isolates were Gram positive, cocci, non-motile, non-spore formers and negative to catalase activity, belonging to Lactococcus spp.

In summary, according to the above tests, it was confirmed up to the genus level that all strains were LAB and among them 6 were Lactobacillus spp (Table 2).

The main physiochemical characteristics of Idli batter fermentation is lactic acid formation. It can be noted by changes in the $\mathrm{pH}$ and titratable acidity. Figures 1 shows the changes of titratable acidity and $\mathrm{pH}$ occurred during fermentation of $i d l i$ batter. The measurements were taken at $4 \mathrm{~h}$ intervals from during $0-32 \mathrm{~h}$ period. During fermentation, titratable acidity increased after $8 \mathrm{~h}$ of fermentation of Idli batter from 0.24 to $0.32 \%$ and the titratable acidity remained steady up to 20 $\mathrm{h}$, and rose to $0.52 \%$ at 24 and $28 \mathrm{~h}$, with a further rising at $32 \mathrm{~h}$.

During fermentation of Idli batter, $\mathrm{pH}$ dropped steadily from 6.28 to 3.72 while titratable acidity increased from 0.24 to $0.92 \%$ during the period of 0 to $32 \mathrm{~h}$ of fermentation. Even though the fermentation temperature varied between 25 and $37^{\circ} \mathrm{C}$, the same observation has been recorded in several studies (Rajalakshmi and Vanaja, 1967; Soni and Sandhu, 1989; Soni and Sandhu, 1990; Ghosh and Chattopadhyay, 2012; Thakkar et al., 2015).

Table 2: Biochemical characterization of the LAB isolates from idli batter

\begin{tabular}{clccc}
\hline Isolate & Gram reaction & Motility & $\begin{array}{c}\text { Spore forming } \\
\text { ability }\end{array}$ & $\begin{array}{c}\text { Catalase } \\
\text { activity }\end{array}$ \\
\hline I-1 & Gram positive, cocci in tetrad & Non motile & Nil & Negative \\
I-2 & Gram positive, Rod shaped bacilli & Non motile & Nil & Negative \\
I-3 & Gram positive, cocci in tetrad & Non motile & Nil & Negative \\
I-4 & Gram positive, cocci in tetrad & Non motile & Nil & Negative \\
I-5 & Gram positive, cocci in tetrad & Non motile & Nil & Negative \\
I-6 & Gram positive, Rod shaped bacilli & Non motile & Nil & Negative \\
I-7 & Gram positive, Rod shaped bacilli & Non motile & Nil & Negative \\
I-8 & Gram positive, Rod shaped bacilli & Non motile & Nil & Negative \\
I-9 & Gram positive, Rod shaped bacilli & Non motile & Nil & Negative \\
I-10 & Gram positive, Rod shaped bacilli & Non motile & Nil & Negative \\
\hline
\end{tabular}






\section{Figure 1. Change of $\mathrm{pH}$, titratable acidity (TA) and lactic acid bacteria (LAB) count in idli batter during fermentation}

The increasing acidity in idli batter mainly depends on Streptococcus faecalis as it produces lactic acid and reduces the $\mathrm{pH}$, increases $\mathrm{CO}_{2}$ concentration in the batter, which leavens batter property (Mukherjee et al., 1965). With the growth of LAB, the $\mathrm{pH}$ of batter decreases (Figure 1). The reduction of $\mathrm{pH}$ of batter helps the activity of yeastas the optimum $\mathrm{pH}$ for yeast ranges from 4.4 to 4.5 (Soni and Sadhu, 1990).

The LAB count increased from 7.55 to 9.88 $\log _{10} \mathrm{cfu} / \mathrm{g}$ during fermentation. High LAB count was observed after $12 \mathrm{~h}$ of fermentation of idli batter where the $\mathrm{pH}$ level was noted as 4.64 (Figure $1)$. The count was reduced with the increment of acidity. After $12 \mathrm{~h}$ of fermentation the LAB count dropped drastically from 9.88 to $5.91 \log _{10} \mathrm{cfu} / \mathrm{g}$ during $32 \mathrm{~h}$ of fermentation. It may be due to increased acidity which may not favourable to LAB population.

The sensory quality of Idli prepared at different fermentation time intervals was analysed. The colour, appearance, taste, texture, mouth feel and the overall acceptability were taken into the analysis. The Idli prepared following $12 \mathrm{~h}$ of fermentation showed maximum desirable sensory quality where $\mathrm{pH}$ and acidity were 4.64 and $0.4 \%$, respectively. Idli prepared with the batter

fermented for 4 and $16 \mathrm{~h}$ scored less for the overall acceptability. It may be due to the characteristic flavour and taste that may develop with prolonged fermentation. Four hour of fermentation might have been not adequate to develop the desirable sensory attributes. Following $16 \mathrm{~h}$ of fermentation, higher acidity the sourness may be increased and the activity of microorganisms may cause undesirable texture of Idli. It may be the reason for the score of overall acceptability may be decreased (Figure 2). The maximum score of sensory quality was obtained at the LAB count noted high in number in the batter which was at $8 \mathrm{~h}$ and $12 \mathrm{~h}$ of fermentation time. Therefore, it indicates that LAB contribute to the textural and over all acceptability improvement of Idli batter. The same results were stated by different authors (Lee, 2001, Thakkar et al., 2015) as when the $\mathrm{pH}$ and acidity randomly within the range of $4.0-4.5$ and $0.5-0.6 \%$ at the time of fermentation showed optimum taste. One of the important invitro probiotic attributes that should be considered from the standpoint of safety before application of probiotic potential LAB in food that is antibiotic susceptibility. The fermented foods which have LAB may act as a pool to transfer antibiotic resistance genes to the pathogens through food or directly to the pathogens which are available in the gastro-intestinal tract while consumption of fermented foods (Lee et al., 2012), (Coppola et al., 2005; Toomey et al., 2009; Erginkaya et al., 2018). This study reports susceptibility profile of ten strains which were isolated from idli batter against different antibiotics such as Ciprofloaxacin, Chloromphenicol, Amoxicillin and Erythromycin using the disc diffusion method. The inhibition zone was measured after $24 \mathrm{~h}$ of incubation. 


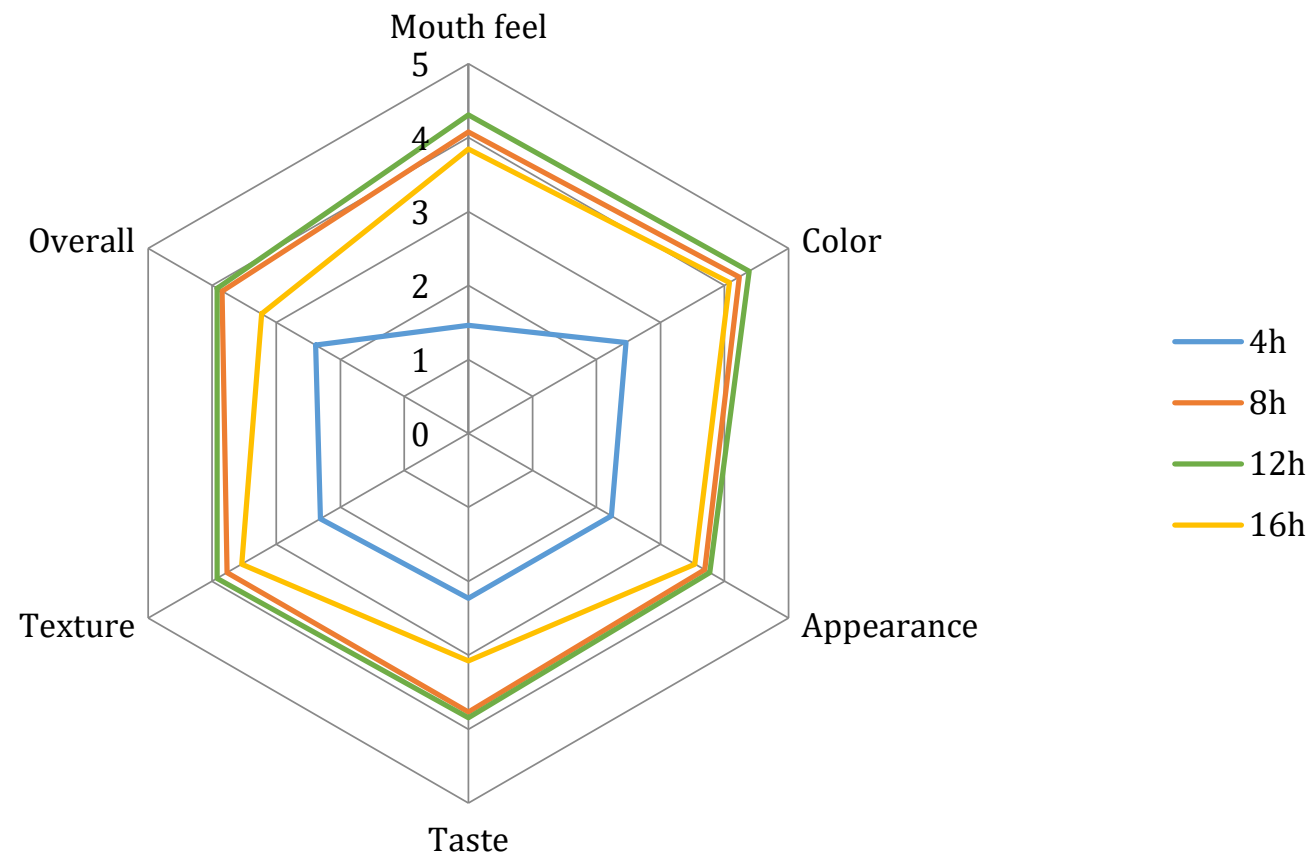

Figure 2. Web diagram depicting sensory attributes of idli prepared using different fermentation durations.

It was revealed that susceptibility to antibiotics highly varied among isolates. Most of the isolates from idli batter were sensitive to the major classes of antibiotics which are commonly used for therapeutic purposes and hence there appears to be a very low risk of possessing antibiotic resistant genes. It may be one of the reasons that the isolates are not more exposed to clinical antibiotics as they are wild strains. While, the commercially used LAB are more resistant to antibiotics as they regularly subjected to different drugs and environments during treatments (Erginkaya et al., 2018), hence they serve as pool of antibiotic resistant genes (Toomey et al., 2009).

Among the antibiotics tested, Ciprofloaxacin was effective against all isolates except I-1 and I-10, while Chloromphenicol usage was effective against all isolates other than isolates I-4 and I-8 (Tables 3 and 4). Similar findings have been recorded in previous studies that Chloromphenicol was sensitive to LAB isolated from idli batter (Patel et al., 2012).



\begin{tabular}{|c|c|c|c|c|}
\hline Isolate & $\begin{array}{r}\text { Ciprofloaxacin } \\
(5 \mu \mathrm{g} / \mathrm{disc})\end{array}$ & $\begin{array}{r}\text { Chloromphenicol } \\
(30 \mu \mathrm{g} / \mathrm{disc})\end{array}$ & $\begin{array}{r}\text { Amoxicillin } \\
(10 \mu \mathrm{g} / \mathrm{disc})\end{array}$ & $\begin{array}{r}\text { Erythromycin } \\
(15 \mu \mathrm{g} / \mathrm{disc})\end{array}$ \\
\hline $\mathrm{I}-1$ & $8.3 \pm 0.58^{b}$ & $15.3 \pm 1.53^{\mathrm{bc}}$ & $23.3 \pm 0.58^{d}$ & $2.00 \pm 1.00^{a}$ \\
\hline $\mathrm{I}-2$ & $19.0 \pm 1.00^{\mathrm{e}}$ & $24.3 \pm 0.58^{f}$ & $1.67 \pm 0.58^{a}$ & $1.7 \pm 1.15^{\mathrm{a}}$ \\
\hline $\mathrm{I}-3$ & $20.7 \pm 0.5^{\mathrm{ef}}$ & $21.7 \pm 1.15^{\mathrm{ef}}$ & $13.0 \pm 1.00^{\mathrm{bc}}$ & $24.7 \pm 1.15^{e}$ \\
\hline $\mathrm{I}-4$ & $23.3 \pm 1.53^{f}$ & $12.3 \pm 1.53^{b}$ & $28.3 \pm 1.53^{e}$ & $21.7 \pm 0.57^{\mathrm{e}}$ \\
\hline $\mathrm{I}-5$ & $11.3 \pm 1.53^{c}$ & $17.0 \pm 1.00^{\mathrm{cd}}$ & $13.3 \pm 0.58^{\mathrm{bc}}$ & $6.3 \pm 1.53^{c}$ \\
\hline $\mathrm{I}-6$ & $20.0 \pm 1.00^{e}$ & $24.3 \pm 1.53^{f}$ & $2.00 \pm 1.00^{\mathrm{a}}$ & $5.33 \pm 0.58^{\mathrm{bc}}$ \\
\hline $\mathrm{I}-7$ & $15.7 \pm 1.15^{d}$ & $19.0 \pm 1.00^{\mathrm{de}}$ & $22.3 \pm 1.52^{\mathrm{d}}$ & $23.3 \pm 1.53^{\mathrm{e}}$ \\
\hline $\mathrm{I}-8$ & $21.7 \pm 0.58^{\mathrm{ef}}$ & $4.33 \pm 0.58^{a}$ & $11.7 \pm 1.15^{b}$ & $2.33 \pm 0.58^{\mathrm{ab}}$ \\
\hline I-9 & $10.3 \pm 0.58^{\mathrm{bc}}$ & $15.0 \pm 1.00^{\mathrm{bc}}$ & $15.6 \pm 0.58^{c}$ & $11.7 \pm 1.15^{d}$ \\
\hline $\mathrm{I}-10$ & $4.0 \pm 1.00^{\mathrm{a}}$ & $17.7 \pm 0.58^{\mathrm{cd}}$ & $23.7 \pm 1.15^{d}$ & $13.3 \pm 1.53^{\mathrm{d}}$ \\
\hline
\end{tabular}

Each value in the table was represented as mean \pm SD $(n=30)$. Values in the same column followed by a different letter (a-b) are significantly different $(p<0.05)$. 
Table 4. Profile of antibiotic susceptibility of LAB isolates

\begin{tabular}{ccccc}
\hline \multirow{2}{*}{ Isolate } & \multicolumn{4}{c}{ Antibiotic susceptibility } \\
\cline { 2 - 5 } & Ciprofloaxacin & Chloromphenicol & Amoxicillin & Erythromycin \\
\hline I-1 & R & S & S & S \\
I-2 & S & S & R & R \\
I-3 & S & S & I & S \\
I-4 & S & R & S & S \\
I-5 & I & S & I & R \\
I-6 & I & S & R & R \\
I-7 & I & S & S & S \\
I-8 & S & R & I & I \\
I-9 & I & S & S & I \\
I-10 & R & S & S & I \\
\hline
\end{tabular}

R: Resistant, S: Sensitive, I: Intermediate

Among 10 isolates, 8 isolates namely I-1, I-3, I-4, I5, I-7, I-8, I-9 and I-10 were susceptible to Amoxicillin while 7 isolates among 10 isolates namely I-1, I-3, I-4, I-7, I-8, I-9 and I-10 were susceptible to Erythromycin. In other words, Table 3 and 4 summarize the results of antibiotic susceptibility study.

Isolates I-3, I-7 and I-9 were susceptible to all antibiotics, while others were shown resistant to at least one antibiotic. The diameters of the zone of inhibition range from 1-23 $\mathrm{mm}$. The highest zone of inhibition was observed by isolates I- 6 against to Chloromphenicol (23 mm). While, the lowest zone of inhibition was observed by isolates I-2 against to Erythromycin (1 mm).

Adagbada et al (2012) have shown that antibiotics can create diarrhoea by creating gut micro flora imbalance and this can be prevented by probiotics. Resistance to antibiotics by probiotics is important in replacing the normal gut microflora after the

\section{REFERENCES}

Abd El Gawad, I.A., Abd El Fatah, A.M. and $\mathrm{Al}$ Rubbayyi, K.A. (2010). Identification and characterization of dominant lactic acid bacteria isolated from traditional Rayeb milk. Egyptian Journal Dairy Science. 6 (10), 728-735.

Adagbada, A.O., Adesida, S.A. and Akitoye, C.O. (2012). Antibacterial potentials of probiotics. Asian Journal of Pharmaceutical and Health Sciences. 2(2), 346-351.

Ayad, E.H.E. and Shokery, E.S. (2011). Industrial important lactic acid bacteria isolated from therapeutic treatment with antibiotics. It is recommended while using the $\mathrm{LAB}$ for starter culture it should be susceptible to at least to two antibiotics (Shuhadha et al., 2017).

\section{CONCLUSION}

It can be concluded that Lactobacilli spp are the predominant LAB microbial group, involved in natural idli batter fermentation. It changes the biochemical characteristics of the idli batter, subsequently it improves the texture and organoleptic characteristics of final steamed product. Also, the isolated LAB were shown different sensitivity profile between the isolates against antibiotics. It acts as a barrier in the case of prepares a combination of therapy with antibiotics. While considering the usage of LAB from idli batter as a starter culture the multi antibiotics resistivity should be evaluated well to consider them as safe

Egyptian human milk and dairy products. Egyptian Journal Dairy Science. 39(2), 197-207.

Ayad, E.H.E., Nashat, S., El-Sedek, N., Metwally, H. and El-Soda, M. (2004). Selection of wild lactic acid bacteria isolated from traditional Egyptian dairy products according to production and technological criteria. Food Microbiology. 21(6), 715-725.

Barrow, H.L. and Felthman, R.K.A. (1993). Cowman and Steels manual for the identification of medical bacteria. 3rd ed. Cambridge, UK. 
Becking, J.H. (1974). Family 2, Azotobacteriaceae. pp. 253-261. In: Buchanan, R.E. and Gibbons, N.E. (Ed.). Bergey's Manual of Determinative Bacteriology. 8th ed. The Williams and Wilkins Co., Baltimore.

Clementi, F. and Aquilanti, L. (2011). Recent investigations and updated criteria for the assessment of antibiotic resistance in food lactic acid bacteria. Anaerobe. 17(6), 394-398.

Coppola, R., Succi, M., Tremonte, P., Reale, A., Salzano, G. and Sorrentino, E. (2005). Antibiotic susceptibility of Lactobacillus rhamnosus strains isolated from Parmigiano Reggiano cheese. Le Lait. 85(3), 193-204.

De Man, J.C., Rogosa, M. and Sharpe, M.E. (1960). A medium for the cultivation of Lactobacilli. Journal of Applied Bacteriology. 23(1), 130135.

El-Soda, M., El-Zeiney, M., Awad, S., Osman, G., Omarn, N., Gamal, G., Ezzat, N. and El Shafei, H. (2003). A culture collection of lactic acid bacteria isolated from raw milk and traditional Egyptian dairy products. Egyptian Journal Dairy Science. 31(1), 23-41.

Erginkaya, Z., Turhan, E.U. and That, D. (2018). Determination of antibiotic resistance of lactic acid bacteria isolated from traditional turkish fermented dairy products. Iranian Journal of Veterinary Research. 19(1), 53-56.

Gerhardt, P., Murry, R.G.E., Costilow, R. N., Nester, E.W., Wood, W.A., Kreig, N.R. and Phillips, G.B. (1981). Manual of Methods of General Bacteriology. American Society for Microbiology., Washington DC.

Ghosh, D. and Chattopadhyay, P. (2012). Application of principal component analysis (PCA) as a sensory assessment tool for fermented food products. Journal of Food Science and Technology. 6, 9.

Iyer, B.K., Singhal R.S. and Ananthanarayan, L. (2011). Characterization and in vitro probiotic evaluation of lactic acid bacteria isolated from idli batter. Journal of Food Science and Technology. 50(6), 1114-1121.

Lee, K.W., Park, J.Y., Jeong, H.R., Heo, H.J., Han, N.S. and Jeong, K.H. (2012). Probiotic properties of Weissella strains isolated from human faeces. Journal of Anaerobes, 18(1), 96-102.
Lee, C.H. (2001). Fermentation Technology in Korea. 1st edn. Korea University Press, Korea.

Mukherjee, S.K., Albury, M.N., Pederson, C.S., Van Veen A.G. and Steinkraus, K.H. (1965). Role of Leuconostoc mesenteroides in leavening the batter of idli, a fermented food of India, Applied Microbiology. 13(2), 227-231.

National Committee for Clinical Laboratory Standards. (1997). Performance Standards for Antimicrobial Disk Susceptibility Tests. Approved Standard M2-A6 (M100-S7). 6th ed, National Committee for Clinical Laboratory Standards, Wayne, Pennsylvania.

Pal, V., Jamuna M. and Jeevaratnam, K. (2005). Isolation and characterization of Bacteriocin producing lactic acid bacteria from a south Indian special dosa (appam) batter. Journal of culture collections. 4, 53-60.

Patel, A., Lindström, C., Patel, A., Prajapati, J.B. and Holst, O. (2012). Probiotic properties of exopolysaccharide producing lactic acid bacteria isolated from vegetables and traditional Indian fermented foods. International Journal of Fermented Foods. 1(1), 87-101.

Rajalakshmi, R. and Vanaja, K. (1967). Chemical and biological evaluation of the effects of fermentation on the nutritive value of foods prepared from rice and grams. British Journal of Nutrition. 21(2), 467-473.

Rangaswami, G. and Bagyaraj, D.J. (1993). Microbial Biotechnology. In: Agricultural Microbiology (eds.). Prentice Hall of India Pvt. Ltd., New Delhi.

Reddy, N., Sathe S, Pierson, M., and Salunkhe, D. (1982). Idli, an Indian fermented food: A review. Journal of Food Quality. 5(2), 89-101.

Rodríguez-Alonso, P., Fernández-Otero, C., Centeno, J.A. and Garabal, J.I. (2009). Antibiotic resistance in lactic acid bacteria and Micrococcaceae/ Staphylococcaceae isolates from artisanal raw milk cheeses, and potential implications on cheese making. Journal of Food Science. 74, 284-293.

Shetty, K., Paliyath, G., Pometto, A. E. and Levin, R. (2005). Food Biotechnology. p. 1973. 2nd ed. CRC Press. USA.

Shuhadha, M. F. F., Panagoda, G. J., Madhujith, T. and Jayawardana, N. W. I. A. (2017). Evaluation of 
probiotic attributes of Lactobacillus sp. Isolated from cow and buffalo curd samples collected from Kandy. Ceylon Medical Journal. 62, 159166.

Soni, S.K., and Sandhu, D.K. (1989). Nutritional improvement of Indian dosa batters by yeast enrichment and black gram replacement. Journal of Fermentation and Bioengineering. $68,52-55$.

Soni, S.K. and Sandhu D.K. (1990). Indian fermented foods: microbiological and biochemical aspects. Indian Journal of Microbiology. 30, 135-157.

Soni, S., Sandhu, D., Vilkhu, K. and Kamra, N. (1986). Microbiological studies on Dosa fermentation. Food Microbiology. 3(1), 45-53
Thakkar, P.N., Modi, H.A., Dabhi, B.K. and Prajapati, J.B. (2015). Evaluation of probiotic potential of Lactic acid bacteria isolated from South Indian special Dosa batter. International Journal of Pharmaceutical Science and Health Care. 5(3), 2249-5738.

Toomey, N., Monaghan, A., Fanning, S. and Bolton, D. (2009). Transfer of Antibiotic Resistance Marker Genes between Lactic Acid Bacteria in Model Rumen and Plant Environments. 75(10), 3146-3152.

Wickramanayake, T.W. (2002). Food and Nutrition. Reprinted HARTI, Sri Lanka. 